\title{
SPRING DISCHARGE RECORDS - A CASE STUDY
}

\section{HIDROGRAMI KRAŠKIH IZVIROV: ŠTUDIJA NA PRIMERU IZVIRA DEVILS ICEBOX (MISSOURI, ZDA)}

\author{
Carol M. WICKS ${ }^{1 \star}$
}

\begin{abstract}
UDC 556.36:551.44(737.8)

Carol M. Wicks: Spring discharge records - a case study

Spring discharge records integrate of all the processes and the reactions occurring within a karst basin. A brief summary of the use of discharge records as a means to constrain the internal structure of karst basins, as means to constrain rainfallrunoff models for karst basin, and as a means to determine the value of hydrodynamic parameters of karst basins is presented. Data collected from Devils Icebox, a karst basin spring in Missouri, USA, were used to assess these approaches to characterizing karst basins. For Devils Icebox, most of the discharge responses do not record information about the internal structure of the basin rather the responses record information about the recharge to the basin. A rainfall-runoff model failed to reproduce the data from which model parameters were derived and has little utility in a predictive mode. Use of conservation of mass equations as a means to derive hydrodynamic parameters is a useful approach, although critical data are lacking. More generally, karst hydrologists need quantitative tracer data and long-term, high-resolution temporal data of the input(s) to and the output(s) from karst basins.
\end{abstract}

Keywords: Hydrograph, hydrology, karst.
Izvleček

UDK 556.36:551.44(737.8)

Carol M. Wicks: Hidrogrami kraških izvirov: študija na primeru izvira Devils Icebox (Missouri, ZDA)

Hidrogrami so vsota procesov in reakcij v kraškem zaledju izvira. Članek nudi kratek pregled uporabe hidrogramov pri določitvi notranje strukture kraškega vodonosnika, izboljšanju modelov napajanja in praznenja ter določanja hidrodinamičnih parametrov kraškega zaledja. Pri tem uporabimo podatke iz kraškega izvira Devils Icebox. V primeru tega izvira hidrogrami ne povedo veliko o notranji strukturi vodonosnika, zato pa več o napajanju zaledja. Model polnjenja in praznenja vodonosnika ni vrnil vhodnih podatkov iz katerih smo določili modelske parametre in je neuporaben za napovedovanje. Uporaba principa ohranitve mase za določanje hidrodinamičnih parametrov, je dober pristop, a so $\mathrm{v}$ našem primeru manjkali nekateri ključni podatki. Kraški hidrologi potrebujejo več kvantitativnih podatkov sledenj in dolge časovne nize podatkov o dotoku in iztoku $\mathrm{z}$ visoko časovno ločljivostjo.

Ključne besede: Hidrogram, hidrologija, kras.

\section{INTRODUCTION}

From the early 1900s to the present, the structure and functioning of karst basins (springsheds) has been inferred from the physical responses of those basins to recharge events (Ashton 1966; Ford \& Williams 2007;
Hess \& White 1988; Vesper \& White 2003). The historical and continued use of hydrographs has been driven by the idea that the output from a karst basin records information about the reactions and the processes that

\footnotetext{
${ }^{1}$ E235 Howe-Russell-Kniffen Geosciences Complex, Department of Geology and Geophysics, Louisiana State University, Baton Rouge, LA 70803, e-mail: cwicks@lsu.edu

Received/Prejeto: 15.2.2013
} 
occur within the basin (White 2002; 2007). Thus, the spring discharge was and is seen as an integration of all the processes and the reactions occurring within that basin. The present article is an overview of the use of hydrographs as a means to constrain the internal structure of basins (White \& Deike 1989), as means to constrain rainfall-runoff models (Labat et al. 1999), and as a means to determine the value of hydrodynamic parameters (Dreiss 1989b; Ferrick 2005).

\section{INTERNAL STRUCTURE}

Whether the physical and chemical responses of karst basins to recharge events carry information about the internal structure of a karst basin or carry information about the intensity and duration of the recharge event has been the subject of considerable research. Early interpretations were based on the assumption that the responses carried information about the internal structure of the basin. Thus, an exponential decay relation was used to derive values for characteristic response times for draining the conduits, the fractures, and the rock matrix that are present in karst basin (Ford \& Williams 2007). Subsequently, researchers interpreted the responses in terms of unexplorable passages (Ashton 1966), the proportion of air-filled passages (Brown 1970; Brown 1973), the presence of constrictions (Halihan \& Wicks 1998; Halihan et al. 1998; Vineyard, 1958) or fine structures (Hess \& White 1988), the geometry of submerged conduits (Grasso et al. 2003a; Grasso et al. 2003b) or of the basin (Kovács \& Perrochet 2008; Kovács et al. 2005), and the ratio of the surface area to volume of conduits (Birk \& Hergarten 2010; Birk et al. 2004). As the number of feasible interpretations increased, the purposefully ambiguous terms of quick and slow flow were used to describe the observed physical responses of karst basins to recharge events (White 2007). Yet, all of these interpretations are based on the assumption that the spring responses actually record information about the internal structure of the basin. Recently, a dimensionless number that can be used to determine whether the discharge hydrograph does record information about the internal structure of a basin or about the input hydrograph to that basin has been defined (Covington et al. 2009); however use the dimensionless number requires information about both the input function and the spring response. Given the current state of knowledge, how should the physical and chemical responses of karst basins be interpreted?

\section{RAINFALL-RUNOFF MODELS}

The goal of rainfall-runoff modeling is to predict discharge (output) from a basin for a given recharge (input) event (Dooge 1959). The rainfall-runoff models were first applied to karst basins by analyzing the records of daily rainfall into and springflow out of three karst basins (Knisel 1972). The rainfall-runoff model is based the definition of a transfer function (kernel function, unit hydrograph). Commonly, a single, linear transfer function has been derived (Dreiss 1983; Hoke \& Wicks 1997; Wicks \& Bohm 2000). Some researchers are developing nonlinear transfer functions (Denic-Jukic \& Jukic 2003) or combining rainfall-runoff modeling with hydrograph separation to derive the most useful relation between rainfall and runoff (Pinault et al. 2001a; Pinault et al. 2001b). However, numerous studies have pointed out that the response of karst basins is inherently non-linear and non-stationary (Labat et al. 2000a; 2000b; 2002). Thus, the question is 'Can rainfall-runoff models be applied to karst basins?'.

\section{HYDRODYNAMIC CHARACTERISTICS}

The conservation of mass equations are widely used throughout the hydrologic sciences to explain the diffusion of flood surges (Ferrick 2005; Ferrick \& Goodman 1998) and the advection and dispersion of solutes (Dingman 1984; Freeze \& Cherry 1979). When solved using appropriate initial and boundary conditions, these governing equations permit the determination of the hydrodynamic characteristics of streams and groundwater. Within karst hydrology, application of these equations has been associated with movement of tracers (Dreiss 1989b; Field \& Leij 2012). The movement of flood surges, which have been noted to travel quickly (Ford \& Williams 2007; White 1988) and the transport of solutes or contaminants (not tracers) have rarely been investigated using conservation of mass equations. What can karst hydrologists learn through thoughtful application of time moment analysis or the advectiondispersion type equations?

\section{OBJECTIVES}

The objective of the current research is to begin to address the questions: "How should the physical and chemical responses of karst basins to recharge events be interpreted?", "Can rainfall-runoff models be applied to karst basins?", and "What can karst hydrologists learn through thoughtful application of time moment analysis or the advection-dispersion type equations?". The approach taken is that of a case study in which all of these questions are addressed for the same basin, Devils Icebox basin. 


\section{MATERIALS AND METHODS}

Devils Icebox basin is in Boone County in central Missouri USA and it is where the endemic pink planaria are found. Even though the basin is small $\left(32 \mathrm{~km}^{2}\right)$ and the length of the mapped passage is modest $(\sim 10 \mathrm{~km})$, the number of scientific studies that have been conducted in the basin is relatively high. The studies include role of chert in controlling passage development and location (Hargrove 1968), water quality (Lerch et al. 2001; Wicks \& Engeln 1997), sediment transport (Dogwiler \& Wicks
2004), and the studies of the pink planaria (Sutton 2004; Wicks et al. 2010). A detailed description of the basin is provided in the cited works and will not be repeated here. Briefly, the areal extent of the Devils Icebox basin is well defined (Vandike 1983; Vandike \& Schulte 1984) and the location of cave passages and stream channels are well known (Deike et al. 1960). There is a primary stream channel linking the losing stream to the spring and that stream channel is wide (relative to depth) and sinuous with impermeable sides; and the in-cave stream has a free surface. Nearly all of the water flowing along the in-cave stream is from the losing surface stream and only a minor portion is delivered via sinkholes and seepage (Wicks 1997a). The discharge and specific conductance data that were collected from Devils Icebox are presented in Lerch et al. (2001) and in Fig. 1. Nine storm events were recorded over the time period and those storms are indicated in Fig. 1.

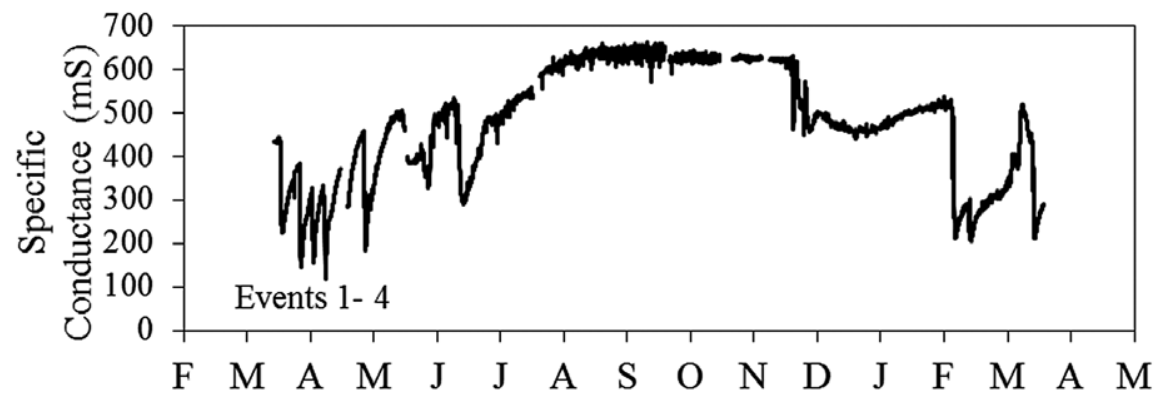

Fig. 1: Record of discharge (plotted as logarithm of discharge; upper panel) and specific conductance (lower panel) from Devils Icebox cave for April 1999 to March 2000 including nine recharge events.

\section{INTERPRETATIONS}

\section{INTERNAL STRUCTURE}

An exponential decay relation has been used to derive values for the characteristic response time for draining conduits, fractures, and rock matrix that are present in a karst basin (Ford \& Williams 2007). Plotting the logarithm of discharge against time allowed the identification of three linear segments (conduits, fractures, and rock matrix). For Devils Icebox, only two linear segments are obvious (Fig. 2). Certainly, the conceptual model of con- duits, fractures, and rock matrix is valid; however, the interpretation of the exponential approach is problematic as the draining of one of the components is not apparent in the response of the basin to recharge events (Fig. 2).

The discharge from the Devils Icebox was described as flow past a constriction and draining of pooled water (Vineyard 1958). In a test of that conceptual model, high-flow events were successfully modeled using a reservoir-constriction model (Halihan \& Wicks 


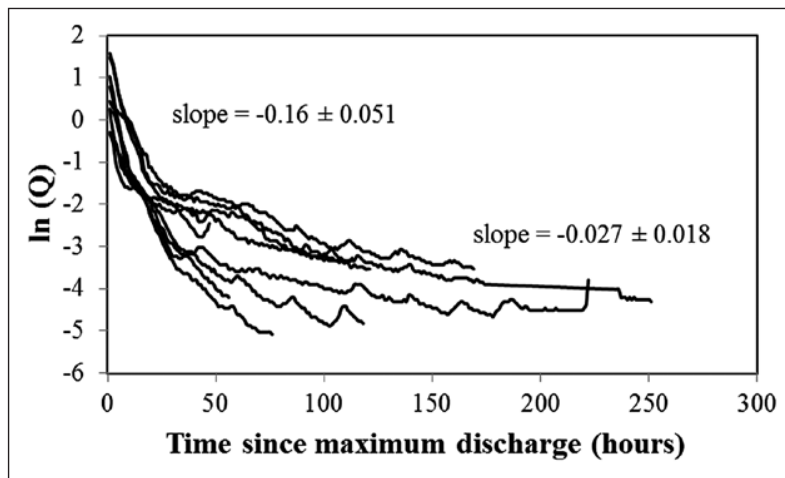

Fig. 2. Plot of the natural logarithm of the discharge for each of the nine recharge events as a function of time since maximum discharge. Note that there are two linear segments; one for higher discharges (early times) and the other for lower discharges (later times). Values of the mean plus and minus one standard deviation of the slopes are given.

1998; Halihan et al. 1998). However, Covington et al. (2009) have shown that many of the physical responses to recharge events recorded at the Devils Icebox record information about the input function and do not reveal information about the internal structure of the basin, such as the presence of constrictions. Can these differ- ent interpretations, that of Halihan and that of Covington, be reconciled? Under typical flow conditions, such as those used in the study by Covington et al. (2009), the discharge from the Devils Icebox reflects input hydrographs. Under high flow conditions, such as those used in the study by Halihan and Wicks (1998), the spring hydrographs do record the presence of the flowpath constriction and pipe-full conditions within the normally air-filled passageways. For Devils Icebox, spring hydrographs record information about the input to the basin and not information about the internal structure of the basin. For rarer extremely high discharge events, the spring discharge does record information about the internal constrictions and pipe-full conditions.

Moving forward, karst hydrologists should instrument both springs and losing reaches for extended periods, including droughts and floods, in order to place any individual results into appropriate hydrologic context. In the simplest case, the data recorded would include depth (stage) of water as a function of time. Researchers could then easily compare the output hydrograph (spring discharge) to the input hydrograph (losing reach hydrograph) and determine whether the spring hydrographs were recording information about the input hydrograph or about the internal structure. Having the input hydro-

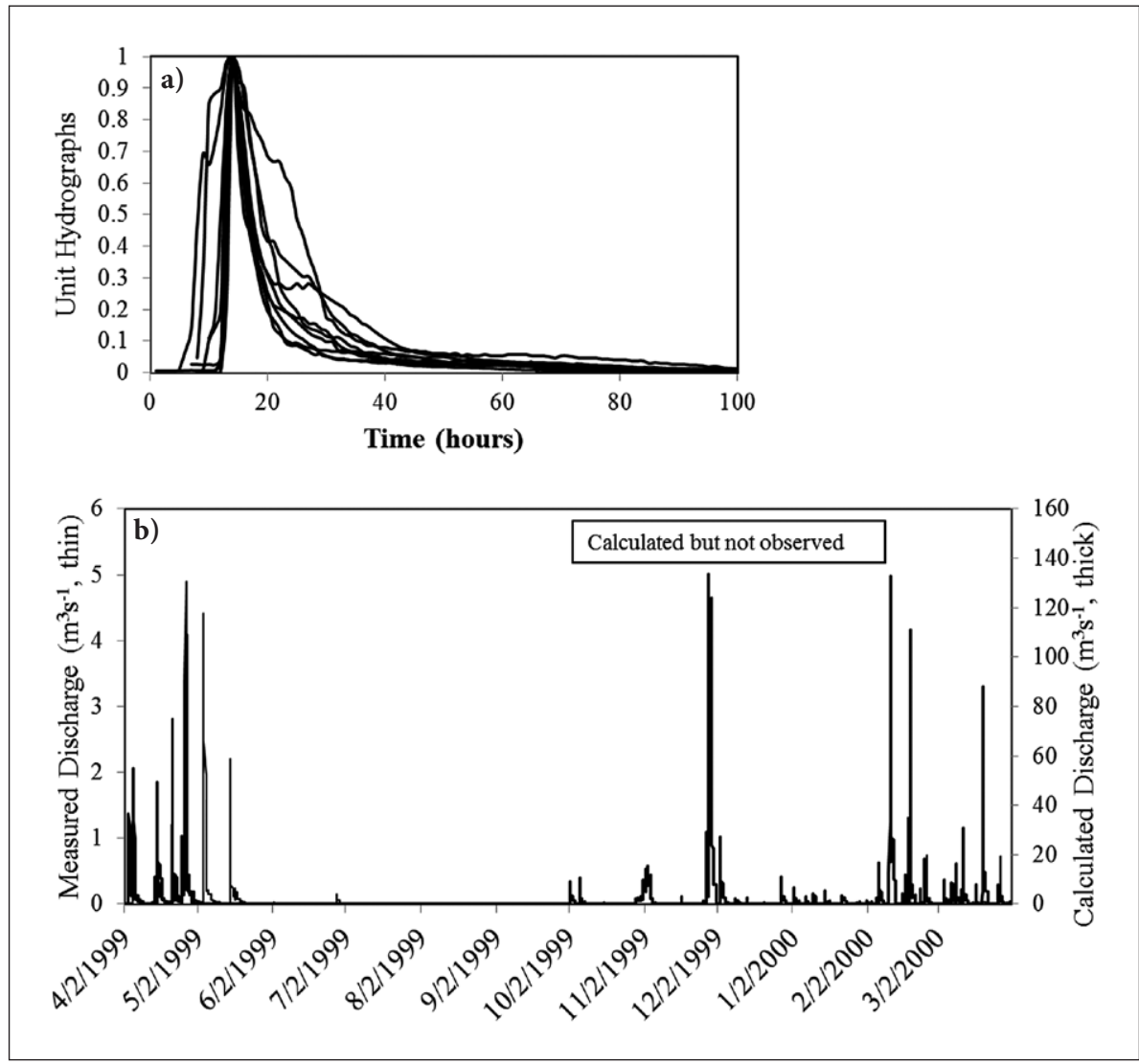

Fig. 3: a) Unit hydrographs derived from each of the nine recharge events noted in Fig. 1 are plotted against time. $b$ ) The measured discharge (thin line; lefthand vertical axis) is compared to the discharged calculated by using a representative unit hydrographs, the rainfall record adjusted for potential evapotranspiration, and the basin area (thick line; right-hand vertical axis). Note the magnitude difference between the two vertical axes, the presence of measured discharge events that were not calculated (near May and June 1999), and the presence of calculated events that were not real events (near Dec 1999). 
graph data is critical to our efforts to knowing how to interpret the response of these basins.

\section{RAINFALL-RUNOFF MODEL}

Rainfall-runoff models relate aerially distributed rainfall to runoff at a particular location along a stream, usually a location with a gaging station, through a transfer function (Dreiss 1983). Deriving a unit hydrograph is the simplest method of determining a transfer function. For Devils Icebox, unit hydrographs (Fig. 3a) were calculated for each of the nine discharge events (Fig. 1). Variation in the unit hydrographs is apparent with some having smaller widths at a dimensionless height of 0.5 compared to other unit hydrographs. This variation points out the difficulty of selecting a single unit hydrograph to serve as the representative transfer function. Further, once that representative transfer function is selected, the calculations of discharge made using that a single transfer function (along with rainfall record corrected for evapotranspiration and the basin are) do not match the data from which the transfer function was derived (Fig. 3). There are events that were calculated to have occurred when measured events are lacking (near Dec 1999); and there are measured events for which no calculated event occurred (May and June 1999).

Fundamentally, a rainfall-runoff model is a water balance for a basin. For the Devils Icebox, the surface area of the basin that drains to the spring is well known (Lerch et al. 2005). That surface area includes land that drains into the losing stream and surface area that drains downward through the sinkhole plain. Even though the basin is well known, the water balance has not been closed, mainly due to an ungaged overflow channel that funnels out of the basin during high-flow events (Wicks 1997b). Research focused on Big Spring and on Maramec Spring basins (also in Missouri, USA) showed that the match between the observed discharged and the discharge calculated based on rainfall-runoff model was poor (Dreiss 1989a; 1989b). Unless the water balance for a particular karst basin can be closed, there is limited use for rainfall-runoff model for that basin. For the Devils Icebox, $\sim 90 \%$ of the water that exits at the spring during recharge events had a source in the losing stream. Thus, a surface runoffspring discharge (a runoff-runoff) model might be more appropriate for predicting the timing and magnitude of the peak discharge. This concept also aligns with our understanding that the spring discharge records information about the input function (surface runoff) and not about the internal structure of the basin. Such a runoff-runoff model requires that the losing stream be monitored over the same time and us- ing the same sampling interval as is used for the spring discharge record. Data from the losing stream were not collected.

\section{HYDRODYNAMIC CHARACTERISTICS}

Solution to the linear diffusion equation (conservation of mass) that governs the diffusion of flood surges (Ferrick 2005; Ferrick \& Goodman 1998) permits the determination of the celerity and noninertial diffusion coefficient. For the Devils Icebox, the calculated celerity and noninertial diffusion coefficient ranged from $0.05-0.78 \mathrm{~m} \mathrm{~s}^{-1}$ and from $0-10 \mathrm{~m}^{2} \mathrm{~s}^{-1}$, respectively (Wicks \& Loper 2008). Thus, the celerity at which storm surges move along in-cave streams is within the range and toward the lower values reported for rivers ( 0.0 to $3.8 \mathrm{~m} \mathrm{~s}^{-1}$; Ferrick 2005). For the Devils Icebox, the values of the diffusion coefficient are higher than values reported for rivers $\left(0.005-0.80 \mathrm{~m}^{2} \mathrm{~s}^{-1}\right.$; Ferrick 2005). The bounding walls of the in-cave stream provide more resistance to flow than the open-back channels of a river, resulting in slower the movement of flood surges (lower celerity) and enhanced diffusion of the flood surge (higher diffusion coefficients).

Solutions to the equations that govern the advection and dispersion of solutes (Freeze \& Cherry 1979) permit the determination of the average effective flow velocity, effective dispersion coefficient, and effective dispersivity (Dreiss 1989b). The values for these parameters should be calculated from tracer test data (Field 2002a; 2002b). For Devils Icebox, these critical data are not available; however, there is a plethora of specific conductance data (Fig. 1). Useful indicators of hydrodynamic parameters can be obtained by using specific conductance data and the moments about the means method (Dreiss 1989b). The coefficient of variation, $\mathrm{C}_{\mathrm{v}}$, is related to the distribution and interconnectedness of the travel flowpaths in the basin and the skewness coefficient, $\gamma$, is related to symmetry of travel distances. For the Devils Icebox, there is one main flowpath from the losing stream to the spring and the interconnection of that flowpath is high, $\mathrm{C}_{\mathrm{v}}$ is low (0.83 to 1.31$)$ as anticipated. The coefficient of skewness for Devils Icebox is also low (0.32 to 0.97), given that there is very little variation in symmetry along one flowpath.

\section{SUMMARY}

Even for the well-studied Devils Icebox basin, critical data (quantitative tracer data, long-term records of discharge at the spring and at the losing streams) are lacking; however, insight into the physical and chemical processes occurring within the basin was possible by applying a combination of approaches. For most recharge events in the Devils Icebox basin, the physical and chemical responses 
of the basin to recharge events should be interpreted as a recorder of information about the input function to that basin and not as a recorder of information about the internal structure of the basin. For infrequent and very large recharge events, the spring discharge does record the development of pipe-full conditions. Developing a runoff-runoff model (contrasted with a rainfall-runoff model) would allow prediction of the timing and duration of peak discharge events. The runoff-runoff model would also sidestep the issue of failure to close the water balance for the basin, as a runoff-runoff model would only track water that flows into the subsurface, effectively closing the water balance. Such a model aligns with our understanding that the spring hydrographs record the input function. For a basin dominated by flow along a single flowpath, the solutions to various conservation of mass equations can provided detailed information about the movement of flood surges and solutes through Devils Icebox.

\section{CONCLUSIONS}

"How should the physical and chemical responses of karst basins to recharge events be interpreted?” For karst basins whether that basin is dominated by in-cave streams or by flow through phreastic conduits, progress can be made by assessing the relation between the discharge hydrograph and the input hydrograph (Covington et al. 2009). If the response records information about the internal structure of the basin, then existing techniques can be used to determine the properties of that internal structure. This requires that we monitor the input to and the output from karst basins over the same time periods and with the same temporal resolution (LeGrand \& Stringfield 1973).

"Can rainfall-runoff models be applied to karst basins?" Rainfall-runoff models (or runoff-runoff models) require that the water budget for a basin can developed. For many karst basins, water budget cannot be developed as the basin area is unknown (or variable depending on flow condition) and lack of appropriate methods to correct precipitation for changes in soil moisture and evapotranspiration. Until water budgets are developed, rainfall-runoff models are of limited utility. Karst hydrologists need to try to close the water balances for the basins that they study.
"What can karst hydrologists learn through thoughtful application of time moment analysis or the advection-dispersion type equations?" Most karst hydrologists commonly record the data needed to determine the value of moments about the mean. With quantitative tracer data, effective dispersivity can be calculated (Dreiss 1989b). Karst hydrologists need to reported the values of a few key parameters (moments about the mean), so that we can develop an understanding of how these parameters vary and so that we can compare those calculated values to values from other karst basins, from surface streams (rivers), and from groundwater basins. These comparison would allow karst hydrologists to place karst hydrology within the broader framework of hydrologic sciences (Herman et al. 2009).

There are fundamental issues to address. We need to routinely monitor the input(s) to and the output(s) from karst basins for long periods of time. Using those data, we need to develop water budgets for basins. We need quantitative tracer data for basins, even in wellcharacterized basins, that permits calculation of key parameters (dispersivity, effective velocities).

\section{ACKNOWLEDGEMENTS}

The Karst Waters Institute organized a conference "Carbon and Boundaries in Karst" that provided the impetus for the preparation of this article. The Karst Hydrology Research Group at LSU reviewed an early version of this article and their comments improved the article. The comments of two anonymous reviewers are greatly ap- preciated and resulted in an improved article. The staff of Rock Bridge Memorial State Park in Missouri provided access to the cave and permitted this study. NSF Grant EAR \#9870423 and AER \#1141745 to C.M. Wicks provided partial support for this study. 


\section{REFERENCES}

Ashton, K., 1966: The analysis of flow data from karst drainage systems.- Transactions of the Cave Research Group, 7, 36-51.

Birk, S. \& S. Hergarten, 2010: Early recession behaviour of spring hydrographs.- Journal of Hydrology, 387, 1-2, 24-32. DOI: 10.1016/j.jhydrol.2010.03.026.

Birk, S., Liedl, R. \& M. Sauter, 2004: Identification of localised recharge and conduit flow by combined analysis of hydraulic and physico-chemical spring responses (Urenbrunnen, SW-Germany).- Journal of Hydrology, 286, 1-4, 179-193.

Brown, M.C., 1970: New methods in karst hydrology.Transactions-American Geophysical Union, 51, 4, 285.

Brown, M.C., 1973: Mass balance and spectral analysis applied to karst hydrologic networks.- Water Resources Research, 9, 3, 749-752.

Covington, M., Wicks, C. \& M. Saar, 2009: A dimensionless number describing the effects of recharge and geometry on discharge from simple karstic aquifers.- Water Resour. Res, 45, 11, W11410.

Deike, G., Hopson, H., Sturmfels, G., Dieke, R., Barnholtz, R. \& K. Lang, 1960: Devils Icebox, Boone County, Missouri. Chouteau Grotto, National Speleological Society, 1 sheet, 1:2740 scale.

Denic-Jukic, V. \& D. Jukic, 2003: Composite transfer functions for karst aquifers.- Journal of Hydrology, 274, 1-4, 80-94.

Dingman, S.L., 1984: Fluvial Hydrology. New York, W.H. Freeman and Company, $383 \mathrm{p}$.

Dogwiler, T. \& C.M. Wicks, 2004: Sediment entrainment and transport in fluviokarst systems.- Journal of Hydrology, 295, 1-4, 163-172.

Dooge, J.C., 1959: A general theory of the unit hydrograph.- Journal of Geophysical Research, 64, 241-256.

Dreiss, S.J., 1983: Linear unit-response functions as indicators of recharge areas for large karst springs.Journal of Hydrology, 61, 31-44.

Dreiss, S.J., 1989a: Regional scale transport in a karst aquifer: 1. Component separation of spring flow hydrographs.- Water Resources Research, 25, 117-125.

Dreiss, S.J., 1989b: Regional scale transport in a karst aquifer: 2 . Linear systems and time moment analysis.- Water Resources Research, 25, 126-134.

Ferrick, M.G., 2005: Simple wave and monoclinal wave models: River flow surge applications and implications.- Water Resources Research, 41, doi:10.1029/2004WR003923, 2005.
Ferrick, M.G. \& N.J. Goodman, 1998: Analysis of linear and monoclincal river wave solutions.- Journal of Hydraulic Engineering, 728-741.

Field, M.S., 2002a: Efficient hydrologic tracer-test design for tracer-mass estimation and sample-collection frequency, 1. Method development.- Environmental Geology, 42, 7, 827-838.

Field, M.S., 2002b: Efficient hydrologic tracer-test design for tracer-mass estimation and sample-collection frequency, 2. Experimental results.- Environmental Geology, 42, 7, 839-850.

Field, M.S. \& F.J. Leij, 2012: Solute transport in solution conduits exhibiting multi-peaked breakthrough curves.- Journal of Hydrology, 440-441, 26-35.

Ford, D.C. \& P.W. Williams, 2007: Karst Hydrogeology \& Geomorphology. John Wiley \& Sons, Inc., New York, 576.

Freeze, R.A. \& J.A. Cherry, 1979: Groundwater. PrenticeHall, Englewood Cliffs, 604.

Grasso, D.A., Jeannin, P.-Y. \& F. Zwahlen, 2003a: Erratum to "A deterministic approach to the coupled analysis of karst springs' hydrographs and chemographs" [Journal of Hydrology 271 (2003) 65-76].Journal of Hydrology, 279, 1-4, 291.

Grasso, D.A., Jeannin, P.Y. \& F. Zwahlen, 2003b: A deterministic approach to the coupled analysis of karst springs' hydrographs and chemographs.- Journal of Hydrology, 271, 1-4, 65-76.

Halihan, T. \& C.M. Wicks, 1998: Modeling of storm responses in conduit flow aquifers with reservoirs.Journal of Hydrology, 208, 1-2, 82-91.

Halihan, T., Wicks, C.M. \& J.F. Engeln, 1998: Physical response of a karst drainage basin to flood pulses: example of the Devil's Icebox cave system (Missouri, USA).- Journal of Hydrology, 204, 1-4, 24-36.

Hargrove, G., 1968: Relation of a chert zone to development of Devils Icebox Boone County Missouri.Missouri Speleology, 10, 15-21.

Herman, E.K., Toran, L. \& W.B. White, 2009: Quantifying the place of karst aquifers in the groundwater to surface water continuum: A time series analysis study of storm behavior in Pennsylvania water resources.- Journal of Hydrology, 376, 1-2, 307-317.

Hess, J.W. \& W.B. White, 1988: Storm response of the karstic carbonate aquifer of southcentral Kentucky.Journal of Hydrology, 99, 235-252.

Hoke, J.A. \& C.M. Wicks, 1997: Contaminant transport in karst aquifers.- The Engineering Geology and Hydrogeology of Karst Terranes. Rotterdam: AA Balkema, 189-192. 
Knisel, W.G., 1972: Response of karst aquifers to recharge, Hydrology Papers. Colorado State University, Fort Collins, CO, 1-51.

Kovács, A. \& P. Perrochet, 2008: A quantitative approach to spring hydrograph decomposition.- Journal of Hydrology, 352, 1-2, 16-29.

Kovács, A., Perrochet, P., Király, L. \& P.-Y. Jeannin, 2005: A quantitative method for the characterisation of karst aquifers based on spring hydrograph analysis.- Journal of Hydrology, 303, 1-4, 152-164.

Labat, D., Ababou, R. \& A. Mangin, 1999: Linear and nonlinear input/output models for karstic springflow and flood prediction at different time scales.Stochastic Environmental Research and Risk Assessment, 13, 5, 337-364.

Labat, D., Ababou, R. \& A. Mangin, 2000a: Rainfall-runoff relations for karstic springs. Part I: convolution and spectral analyses.- Journal of Hydrology, 238, 3-4, 123-148.

Labat, D., Ababou, R. \& A. Mangin, 2000b: Rainfall-runoff relations for karstic springs. Part II: continuous wavelet and discrete orthogonal multiresolution analyses.- Journal of Hydrology, 238, 3-4, 149-178.

Labat, D., Ababou, R. \& A. Mangin, 2002: Multiresolution cross-analysis of rainfall rates and karstic spring runoffs.- Comptes Rendus Geoscience, 334, 8, 551-556.

LeGrand, H.E. \& V.T. Stringfield, 1973: Karst hydrology A review.- Journal of Hydrology, 20, 2, 97-120.

Lerch, R.N., Erickson, J.M. \& C.M. Wicks, 2001: Intensive water quality monitoring in two karst watersheds of Boone County, Missouri.- Proceedings of the 15th National Cave and Karst Management Symposium (October 16-19, 2001), National Cave and Karst Management Symposium Steering Committee, Tuscon, AZ

Lerch, R.N., Wicks, C.M. \& P.L. Moss, 2005: Hydrologic characterization of two karst recharge areas in Boone County, Missouri.- Journal of Cave and Karst Studies, 67, 158-173.

Pinault, J.L., Pauwels, H. \& C. Cann, 2001a: Inverse modeling of the hydrological and the hydrochemical behavior of hydrosystems: Application to nitrate transport find denitrification.- Water Resources Research, 37, 8, 2179-2190.

Pinault, J.L., Plagnes, V., Aquilina, L. \& M. Bakalowicz, 2001b: Inverse modeling of the hydrological and the hydrochemical behavior of hydrosystems: Characterization of karst system functioning.- Water Resources Research, 37, 8, 2191-2204.
Sutton, M., 2004: The pink planarians of Devils Icebox Cave - Census Protocols. Cave Research Foundation, 32.

Vandike, J., 1983: Stream gaging results, upper Bonne Femme Creek - rating curve, Devils Ice Box Spring, Memorandum. Division of Geology and Land Survey, Missouri Department of Natural resources, 1.

Vandike, J. \& S. Schulte, 1984: Devil's Icebox Water Quality Study June 1982 to July 1984, Memorandum, 43.

Vesper, D.J. \& W.B. White, 2003: Metal transport to karst springs during storm flow; an example from Fort Campbell, Kentucky/Tennessee, USA.- Journal of Hydrology, 276, 1-4, 20.

Vineyard, J., 1958: The reservoir theory of springflow.National Speleological Bulletin, 48, 43-53.

White, W.B., 1988: Geomorphology and Hydrology of Karst Terrains. Oxford University Press, Inc., 464.

White, W.B., 2002: Karst hydrology: recent developments and open questions.- Engineering Geology, 65, 2-3, 85-105. Doi: 10.1016/s0013-7952(01)00116-8.

White, W.B., 2007: Brief history of karst hydrogeology: Contributions of the NSS.- Journal of Cave and Karst Studies, 69, 1, 13-26.

White, W.B. \& G.H. Deike, III, 1989: Hydraulic geometry of cave passages.- In: White, W.B. \&White, E.L. (eds.), Karst Hydrology: Concepts from the Mammoth Cave Area, Van Nostrand Reinhold, pp. 223-258. New York.

Wicks, C. \& D. Loper, 2008: A linear model of pressure pulses in karstic aquifers.- AGU Spring Meeting Abstracts, 1, 05.

Wicks, C., Noltie, D.B., Peterson, E.W. \& T. Dogwiler, 2010: Disturbances in the habitat of Macrocotyla glandulosa (Kenk).- Ecohydrology, 3, 1, 116-125.

Wicks, C.M., 1997a: A Hydrologic and Geochemical Model of the Devils Icebox.- Missouri Speleology, $39,3,1-13$.

Wicks, C.M., 1997b: Origins of groundwater in a fluviokarst basin Bonne Femme Basin in central Missouri, USA.- Hydrogeology Journal, 5, 89-96.

Wicks, C.M. \& B. Bohm, 2000: Application of unit hydrograph technique to the discharge record at Big Spring, Carter County, Missouri.- In: Sasowsky, I.D. \& C.M. Wicks, (eds.), Groundwater flow and contaminant transport in carbonate aquifers, A.A. Balkema Publisher, pp. 31-42.

Wicks, C.M. \& J.F. Engeln, 1997: Geochemical evolution of a karst stream in Devils Icebox Cave, Missouri, USA.- Journal of Hydrology, 198, 1-4, 30-41. 